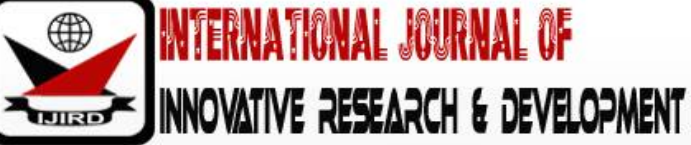

ISSN 2278 - 0211 (Online)

\section{Comparison: Youtube Incorporated with Class Flow and Big Book to Improve Reading Skills among ESL Learners}

\author{
Masnih Binti Musa \\ Teacher, Sekolah Kebangsaan St Mary Labuk (M), Sandakan, Sabah, Malaysia \\ VIvienne Rozanna Matthew \\ Teacher, Sekolah Kebangsaan Kampung Baru, Bintulu, Sarawak, Malaysia \\ Melor Md Yunus, \\ Associate Professor, Faculty of Education, Universiti Kebangsaan Malaysia, Malaysia
}

\begin{abstract}
:
To encourage young ESL learners to involve with any reading materials on their own, it is crucial to use Big Book approach in early literacy. Children need a rich language and conceptual knowledge base, a broad and deep vocabulary, and verbal reasoning abilities to understand messages that are conveyed through print to become a skilled reader. Code-related skills in phonological awareness, repertoire of highly familiar words and alphabetic principle must be developed to make sure it is easily recognized. The Alpha Generation or the digital natives may have different perspectives towards this approach. Hence, another approach needed to put into practice. Therefore, an action research was conducted in the ESL classrooms to compare Big Book approach and digital storytelling via YouTube. This study involved a total number of one hundred participants of Year 1, Year 2 and Year 5 ESL learners from two primary schools in Sandakan, Sabah, Malaysia and Bintulu, Sarawak, Malaysia respectively. Naturalistic observations and contingency table examined participant's attitude towards the approaches, also paired sample t-test as research instruments. The research data showed that digital storytelling via YouTube and Class Flow application as its platform had covered language skills and contributed significantly by fostering pupils' interest in English reading and improving pupils' proficiency. Hence, it is a critical stage to develop and enhance creative and innovative tool in teaching and learning processes to fit these alpha generations.
\end{abstract}

Keywords: Big Book, alpha generation, digital storytelling, YouTube, class flow

\section{Introduction}

It is believed that storytelling has served as a popular education tool, employed to pass knowledge from one generation to another since the earliest recorded human history. Research shows that there is a strong link between reading success in school and early reading experiences at home. Early readers reported that the most prevalent factor among these children was that parents of others read to them from an early age. Similarly, Allington (1983) who studied good and poor readers in school found that overwhelmingly the good readers were the one who were read to at home. Shared reading between parent and child seems to be the foundation for early literacy; the Big Book approach is an extension of this concept into the classroom. Samuels (1979) claimed in order to develop fluency, the method of repeated readings has also been advocated. He contends that a fluent reader decodes text automatically, without conscious attention, leaving the mind free to grapple with comprehension.

\section{Literature Review}

\subsection{Reading}

Today, to become successful in a fast-paced globalized society it is crucial to have the ability to read and grasp everything under the sun especially the sun (Connor et al., 2011). Literacy laid the foundation for learning in primary education and beyond. Hence, the Malaysian Ministry of Education has introduced a programme called Literacy and Numeracy Screening (LINUS) to ensure all Malaysian children acquire basic literacy and numeracy skills after three years of mainstream primary education. By the end of the sixth year of mainstream primary education, there will be an examination for Year Six pupils used as yardstick to measure the proficiency and competency of the pupils in their reading, writing and arithmetic. Maasum \& Maarof (2012) stated that reading skills is very important to gain knowledge and understand written text well. Therefore, it is very important for teacher to ensure pupils acquire essential reading skills and on the same time enable them to learn and enjoy. According to Yunus \& Abdullah (2011), environmental support factors such as teacher, parent and peer support also showed favourable responses towards these students learning the English language. 


\subsection{Big Book}

Leland and Lewison (2018) agreed that a classroom literacy program based on environmental print and literature provides multiple opportunities for pupils to read and write. Sometimes pupils use writing to respond to books or other texts in terms of what they thought and why. The teacher can call attention to how words are written outside the text in a larger font and give pupils an opportunity to try doing that with a story they write. Once pupils use writing to replicate the pattern of a book that has been read to them, they will be able to do the same thing with other books. Besides, Labbo, Eakle \& Montero (2002) claimed that teachers can enhance the benefits of using the language experience approach by adding digital photography. Besides, digital literacy is also about creating an awareness of the standard governing online behavior. The use of technologies is extremely important to make easy access to knowledge.

\subsection{YouTube}

YouTube has been providing interactive educational channels for the past years and researchers believes that higher education institutions need to transform traditional education policy and the trend towards blended e-learning because YouTube is suitable with the requirements and needs of pupils from the Internet generation. keep pace with the developments in the current era as it is also known as the era of the information revolution as stated by Jung, Insung \& Yekyung (2013).

Vanderplank (1993) states that due to the increasing number of foreign language teaching techniques that integrate with the latest technology, such as computers and video materials, the method of language teaching and practices has shifted from the printed word and knowledge of language systems to the use and communicative value of the spoken language in everyday setting. By having this type of condition, learners gradually develop their language acquisition by being exposed to the genuine environment of the target language.

\subsection{Class Flow}

Class Flow is a cloud-based lesson delivery software with advanced collaboration tools. It consists of interactive lessons, activities, quizzes and resources from educators around the world. With ClassFlow, teachers can build and access interactive lessons from any web browser, share lessons with other peers and collaborate using the latest mobile and student response technology. Not only it can save times at the planning and setup stages of any lesson development, but it can also facilitate a more connected classroom. In a simple term, ClassFlow is cloud-based teaching software designed to make lesson preparation easier and lesson delivery more dynamic. As a teacher, we need to understand how to fit in the pupils in learning materials, so they will meet their qualification requirements. So, the teacher roles gain another dimension.

Though, for the past few years, drastic changes have been experienced in the processes used for creating stories, the variety of media used to convey the message, and the target audience. Computers, digital cameras, editing software, and other technologies are becoming more readily accessible in the classroom and provide learners and teachers with the tools to create digital stories more easily than ever before as claimed by Armstrong (2003). In other words, digital storytelling helps pupils to develop their creativity to solve problems in innovative ways, Ohler (2008). Despite sounding very similar to computer literacy, digital literacy comes with a completely different meaning. This is a branch of study that requires a deep understanding of the communal issue emerging out of digital technologies. In a study conducted by Norzila, Fauziah \& Parilah (2007), it is found that pupils favoured a more Formal Authority, Personal Model, Facilitative and Delegator styles. In sync of integrating technology in the teaching and learning process, the researchers include Facilitative style to be incorporated in the English language classroom. Due to that reason, the researchers chose to conduct activities in the classroom through Youtube and ClassFlow. Hence, the researchers would like to study how technology can be integrated in teaching and learning. Therefore, this research aims to compare between the effectiveness of digital storytelling and Big Book approach towards the achievements of ESL learners in primary schools especially in their reading skills.

\section{Methodology and Procedure}

The purpose of the study is to compare between Big Book approach (Method A) and digital storytelling via YouTube and activities conducted through Class Flow (Method B) application as the tools. This research had employed an action research method based on Action Research Model by Kemmiss and McTaggart.The two researchers had identified participants' similar problem regarding their reading fluency. The participants were struggling to learn in reading and acquire information from their reading material. Thus, the researchers were concerned that the participants were still unable to read well and consequently, the participants may face difficulties in the class and may not answering their exam questions well. In short, the researchers may not investigate whether such methods work, but which ones work best. 
- Are there statistically significant differences in reading skills among ESL learners by implementing method A and method B?

- Is there a relationship in ESL learners between the effectiveness of method A and method B in their reading skills?

\subsection{Research Hypothesis}

The hypothesis that the researchers tested and its associated null-hypothesis were:

- H1: There is a significant difference between the implementation of method A and method B in terms of the reading skills among the ESL learners.

- H0: There is no significant difference between the implementation of method A and method B in terms of the reading skills among the ESL learners.

\subsection{Population and Sample}

Purposive sampling method was used to select the samples. This action research was carried out on a total of onehundred primary school participants from two different schools in the northern part of Sarawak, Malaysia and in eastern coast of Sabah, Malaysia. There were listed as followed;

- Group 1; thirty-four pupils from Year 1 (7 years old)

- Group 2; thirty-two pupils from Year 2 (8 years old)

- Group 3; thirty-four pupils from Year 5(10 years old)

The pupils were coming from the intermediate and low achievers. A pre-test was administered by utilizing the Mid Semester Examination and Year-End Examination as the post-test. The following statistical treatments were used in data analysis: paired sample t-test and cross tabulation also known as contingency table.

\subsection{Research Instrument}

Initially, a marathon of storytelling by using a selection of big books was introduced in teaching language arts classroom to the participants. This was where the participants started to experience shared reading in the classroom.

Earlier, most of the participants have never been experienced shared reading of big book before. Initially, to ask participants to sit on the floor in a good manner and comfortably was quite challenging. It was been slightly chaotic at the beginning when the method A implemented as the participants never had chances to listen a reading aloud session beforehand. But in a short time, after few rules carry out, the participants agreed to behave cooperatively.

Next, Class Flow application was applied in the language arts classroom. A selected digital story telling T-Series Kids Hut videos from You Tube was chosen. The researchers used a personal laptop and LCD projector to display activities by using the Class Flow application on the screen. Activities consisted of puzzles, word search and reading comprehension questions. After that, a post-test result was observed for any improvement. The post-test scores analysed using Statistical Package for Social Sciences (SPSS). A paired sample-t test was carried out to test the significance in the difference in score for pre-test and post-test. In order to analyze the relationship between the effectiveness of method A and method B among the participants, the researchers examined a contingency table. This is a table that displays the frequencies and percentages of participants from each category of one variable across the categories of another variable Connolly (2007).

Based from the contingency table data, participants were given a simple question; "How much do you like reading?". The participants were given five choices of responses; 1 = "a lot", 2 = "quite a lot", 3 = "a little", $4=$ "not very much" and 5 ="not at all".

\section{Data Analysis and Results}

\subsection{Naturalistic Observation}

Naturalistic observation involves observing individuals in their natural setting and the researchers makes no efforts whatsoever to manipulate variables or to control the activities of individuals, but simply observes and records what happens as things naturally occur Fraenkel \& Wallen (2006). The researchers had witnessed major changes on the participant's attitudes towards every English Language lesson. Especially on every Thursday, the participants attended to the class happily for the language arts lesson. The participants showed their disappointment if the session was cancelled and plead to replace it sooner. As claimed by Leland and Lewison (2018), they don't advocate testing for a read-aloud program. Instead they recommend that teachers look for changes in their students' action and attitudes. For example, they think one sure sign of success is that kids were begging to hear another chapter or book when the researcher was reading aloud.

Reading aloud as a type of advertising for literacy that gets listeners interested in topics, books, and reading in general. In a nutshell, reading aloud helps to set up the conditions for children and adolescents to follow and to reach out for books so they can pursue their own interests and inquiries. But in this research, the participants are more interested with method A. Participants tend to show their interests towards English language lessons by asking for the storytelling weekly. Based from the researcher's observations, the participants also showed their curiosity on the stories and willing to read them on their own. It was also observed by the researcher that, participants showed improvements in areas particularly in reading comprehension examined in the post test. 
Table 1 indicates the quantitative results obtained from Pre-Test and Post-Test. The scores were

compared to examined if there are any statistically significant differences in reading skills among ESL learners by implementing method A and method B.

\begin{tabular}{|c|c|c|c|}
\hline Group & Pre-Test (\%) & Post-Test (\%) & Percentage of Increment (\%) \\
\hline 1 & 72.6 & 54.4 & -18.2 \\
2 & 83.5 & 90.7 & 7.2 \\
3 & 76.4 & 94.1 & 17.7 \\
\hline
\end{tabular}

Table 1: Total Scores For Pre-Test and Post-Test

Based on Table 1, this can be proven to the above statement that the percentage for group 1 declined $18.2 \%$ from $72.6 \%$ in their pre-test using method A. The researchers suggested that method B did not give any positive impact in their reading fluency as well as their examination score. In contrast to group 2 and group 3 there was a positive development in the pupils' achievements, where the result showed the increased number of passing marks percentage among group 2 and group 3. Before the intervention, 83.5\% of group 2 had passes their examination. After the intervention, it increased to $7.2 \%$. As for group 3, they started with $76.4 \%$, after the intervention, the percentage increased to $17.1 \%$. This indicates that method B had impacted the participants' performance in reading skills particularly on their reading fluency.

On the other hand, method A implied a "readerly identity", this was demonstrated in the table where the percentage of the pre-test started from above $70 \%$ for each group. Reading aloud is important because it encourages people for both young and old to develop a readerly identity. They know how to talk about, what they are reading and how to share their perspectives with other readers who might respond differently. Enjoyment of a text being read aloud leads to people beginning to themselves as an individual, who are interested in reading and this, in turn, encourages them to read more often and to put more energy into their reading lives Leland and Lewison (2018).

\subsection{Paired sample t-test}

\begin{tabular}{|c|c|c|c|c|c|c|c|c|c|}
\hline & \multicolumn{5}{|c|}{ Paired Differences } & \multirow[t]{3}{*}{$\mathbf{t}$} & \multirow[t]{3}{*}{ df } & \multirow{3}{*}{$\begin{array}{c}\text { Sig. } \\
\text { (2-tailed) }\end{array}$} \\
\hline & & \multirow[t]{2}{*}{ Mean } & \multirow[t]{2}{*}{$\begin{array}{c}\text { Std. } \\
\text { Deviation }\end{array}$} & \multirow[t]{2}{*}{$\begin{array}{l}\text { Std. Error } \\
\text { Mean }\end{array}$} & \multicolumn{2}{|c|}{$\begin{array}{c}\text { 95\% Confidence } \\
\text { Interval of the } \\
\text { Difference }\end{array}$} & & & \\
\hline & & & & & Lower & Upper & & & \\
\hline Pair 1 & PreTest - PostTest & -1.92000 & 13.70297 & 1.37030 & -4.63897 & .79897 & -1.401 & 99 & .164 \\
\hline
\end{tabular}

Table 2: Paired Samples Test

$$
\mathrm{p}=0.164>0.05
$$

As indicated in Table 2, there was a significant difference in the score conditions; $t(99)=-1.401, p=0.164$. This is further supported the researcher's hypothesis that there is a significant difference between the implementation of method A and method B in terms of the reading skills among the ESL learners as $p=0.164>0.05$. These results suggest that both methods implied a significant difference among ESL learners especially in their reading comprehension skills, the number of percentages increased.

\subsection{Contingency table}

To further support the statement on the effectiveness between method A and method B intervention, the participants were asked a simple question at the start (Pre-test) and at the end (Post-test) concerning how much they liked reading. For this question they could choose from five responses: "a lot"; "quite a lot"; "a little"; "not very much"; or "not at all". Research question 2: Is there a relationship in ESL learners between the effectiveness of method A and method $B$ in their reading skills? The researchers preceded a cross tabulation option that related to the variable of interested in making comparisons with. In other words, the researchers were interested in comparing children from different group.

\begin{tabular}{|c|c|c|c|c|c|c|c|c|}
\hline \multirow{2}{*}{\multicolumn{3}{|c|}{$\begin{array}{l}\text { "How Much Do You Like } \\
\text { Reading?" }\end{array}$}} & \multicolumn{5}{|c|}{ Atitud1 } & \multirow[t]{2}{*}{ Total } \\
\hline & & & "a lot" & "quite a lot" & "a little" & "not very much" & "not at all" & \\
\hline \multirow{3}{*}{ Group } & 1 & \% within Group & $2.9 \%$ & $29.4 \%$ & $29.4 \%$ & $26.5 \%$ & $11.8 \%$ & $100.0 \%$ \\
\hline & 2 & \% within Group & $\begin{array}{c}18.8 \\
\%\end{array}$ & $9.4 \%$ & $40.6 \%$ & $25.0 \%$ & $6.3 \%$ & $100.0 \%$ \\
\hline & 3 & Count & 0 & 6 & 10 & 18 & 0 & 34 \\
\hline \multirow{2}{*}{\multicolumn{2}{|c|}{ Total }} & Count & 7 & 19 & 33 & 35 & 6 & 100 \\
\hline & & \% within Group & $7.0 \%$ & $19.0 \%$ & $33.0 \%$ & $35.0 \%$ & $6.0 \%$ & $100.0 \%$ \\
\hline
\end{tabular}

Table 3: Method A: Cross tabulation 
Based from the above table, the researchers found out that the number of positive remarks in grey colour by applying method A, which consists of "a lot", "quite a lot" and "a little" shared a total percentage of 59\%. This set as the benchmarking in teaching reading skills at the best level. Meanwhile, for the negative remarks; "not very much" and "not at all" total percentage was $41 \%$, less than $18 \%$ of reading skills acquired from the participants. This illustrated that even though these participants coming from the intermediate and the low achievers, they managed to prove that in order to be able to read successfully, self- interaction with the researcher was crucial in their daily routine. On condition that learners are read to, they see how language works, what it looks like in action, and how rewarding it can be to take part in language events. Through the demonstrations they see as part of a read-aloud experience, students come to understand what a story is, how researchers give life to their stories, and the role of text and picture in conveying meaning. In short, reading is demonstrated as an active process that invites commentary and critique. An added bonus is that all of this knowledge about reading is delivered as a whole package. Students do not learn about turning pages on one day and responding to an author's message on another Leland and Lewison (2018).

\begin{tabular}{|c|c|c|c|c|c|c|c|c|}
\hline \multirow{2}{*}{\multicolumn{3}{|c|}{ “How Much Do You Like Reading?” }} & \multirow{2}{*}{\multicolumn{5}{|c|}{ Atitud2 }} & \multirow{2}{*}{$\begin{array}{c}\text { Total } \\
34 \\
\end{array}$} \\
\hline & & & & & & & & \\
\hline Grou & \multirow[t]{2}{*}{1} & Count & $\begin{array}{c}\text { "a lot" } \\
0\end{array}$ & $\begin{array}{c}\text { "quite a } \\
\text { lot" }\end{array}$ & $\begin{array}{c}\begin{array}{c}\text { "a } \\
\text { little" }\end{array} \\
20\end{array}$ & $\begin{array}{c}\text { "not very } \\
\text { much" }\end{array}$ & $\begin{array}{c}\text { "not at } \\
\text { all" }\end{array}$ & \\
\hline \multirow[t]{5}{*}{$\mathrm{p}$} & & $\%$ within Group & $0.0 \%$ & $17.6 \%$ & $\begin{array}{c}58.8 \\
\%\end{array}$ & $20.6 \%$ & $2.9 \%$ & $\begin{array}{c}100.0 \\
\%\end{array}$ \\
\hline & \multirow[t]{2}{*}{2} & Count & 3 & 12 & 13 & 2 & 2 & 32 \\
\hline & & $\%$ within Group & $9.4 \%$ & $37.5 \%$ & $\begin{array}{c}40.6 \\
\%\end{array}$ & $6.3 \%$ & $6.3 \%$ & $\begin{array}{c}100.0 \\
\%\end{array}$ \\
\hline & \multirow[t]{2}{*}{3} & Count & 0 & 12 & 13 & 8 & 0 & 33 \\
\hline & & $\%$ within Group & $0.0 \%$ & $36.4 \%$ & $\begin{array}{c}39.4 \\
\%\end{array}$ & $24.2 \%$ & $0.0 \%$ & $\begin{array}{c}100.0 \\
\%\end{array}$ \\
\hline \multirow{2}{*}{\multicolumn{2}{|c|}{ Total }} & Count & 3 & 30 & 46 & 17 & 3 & 99 \\
\hline & & $\%$ within Group & $3.0 \%$ & $30.3 \%$ & $\begin{array}{c}46.5 \\
\%\end{array}$ & $17.2 \%$ & $3.0 \%$ & $\begin{array}{c}100.0 \\
\%\end{array}$ \\
\hline
\end{tabular}

Table 4: Method B: Cross Tabulation

Table 4 determined that there were increasing number of $20.8 \%$ in percentage of positive remarks total as

79.8\% by implementing method B. In order to answer the second research questions, "Is there a relationship in ESL learners between the effectiveness of method A and method B in their reading skills?" based from the above findings it was clearly depicted that there was a relationship in ESL learners by using both methods in their reading skills. For younger children and less proficient readers, digital storytelling often has a positive influence in their literacy development and motivation to learn to read. For them, participating in online literacy activities might provide the impetus to keep them engaged in reading and critical language study.

\section{Conclusion and Implication}

Throughout this research, it was concluded that YouTube and Class Flow application had a positive impact towards Group 2 and Group 3 participants in improving their reading skills. It was displayed through their positive responses towards learning and their good scores in reading comprehension test. However, this approach did not suit for Group 1 pupils as they just started to learn to read and recognize alphabets and numerical components. It is suggested that further research can be conducted to investigate other factors that may affect the intervention and new tool of teaching reading.

The researchers revealed that the ESL learners in Level 1 illustrated more appealing to Big Book approach whereas the Level 2 learners preferred digital storytelling. This was proven by the participants' accumulative scores and their responses from the simple questions given before and after both methods were implemented. This research also showed that the tool of teaching storytelling was more fun and suitable to achieve reading comprehension skills. It was displayed through increment percentages of their positive responses. As mentioned by Leland and Lewison (2018), while we certainly want reading aloud be seen by the students as a pleasurable activity, we also want them to see it is as something that is too important to leave out. Even though the participants were not able to use the language all the time, but at least they have shown some reassuring self-motivation to learn the language with enjoyment.

\section{Reference}

i. Allington, R.L (1983). The Reading Instruction Provided Readers of Differing Abilities. Elementary School Journal, $83,548-559$.

ii. Armstrong, S. (2003). The Power of Storytelling in Education, in Snapshots, ed. by Armstrong, S Snapshots! Educational Insights from the Thornburg Centre, pp.11-20.

iii. Baba, A. (1997). Statistik Penyelidikan dalam Pendidikan Sains Sosial. UKM.

iv. Connoly. P. (2007). Quantitative Data Analysis in Education; A Critical introduction using SPSS. Routledge, Taylor \& Francis Group. USA. 
v. Connor, C. M., Morrison, F. J., Fishman, B., Giuliani, S., Luck, M., Underwood, P. S., et al. (2011). Testing the impact of child characteristics $\mathrm{x}$ interactions on third graders' reading comprehension by differentiating literacy instruction. Reading Research Quarterly, 46, 189-221.

vi. Dupain, M., Maguire L. (2005). Digital story book projects 101: How to create and implement digital storytelling into your curriculum.

vii. Fraenkel. J. R \& Wallen. N. E. (1932). How to design and evaluate research in education. McGraw-Hill Companies, Inc. USA.

viii. Grasha, A.F. 1994. A matter of style: The teacher as expert, formal authority, personal model, facilitator, and delegator. College Teaching. 42: 142-149.

ix. Gravetter. F.J. \& Wallnau. L.B. (2009). Statistical for the Behavioural Science. Wadsworth Cengage Learning. USA.

x. Jebamalar \& Asir Anthony (2014). A Practical Approach for Teaching Digital Image Processing with MATLAB. AJTLHE: ASEAN journal of Teaching and Learning in Higher Education. (6) (2) pp. 1-11. ISSN 1985-5826.

xi. Kemmis, S., \& McTaggart, R. (2000). Participatory action research. In N. Denzin \& Y. Lincoln (Eds.),Handbook of qualitative research (2nd ed., pp. 567-605). Thousand Oaks, CA: Sage.

xii. Lim, K.I., Yunus, M.M. \& Embi, M.A (2017). Build Me Up: Overcoming Writing Problems Among Pupils In A Rural Primary School In Belaga, Sarawak, Malaysia. Jurnal Pendidikan Humaniora. 5(1), 1-7.

xiii. Leland. C.H. \& Lewison. M. (2018). Teaching Children's Literature; It's Critical. Routledge, Taylor \& Francis Group. USA.

xiv. Maasum, T.N.R.T.M. \& Maarof, N.(2012). Empowering ESL readers with metacognitive reading strategies. ProcediaSocial and Behavioral Sciences, 69, 1250-1258.

xv. Norzila, Fauziah \& Parilah (2007). Perceived and Preferred Teaching Styles (Methods) of English for Specific Purposes (ESP) Pupils. e-bangi: Journal Sains Sosial \& Kemanusiaan, 2(2). p.20 ISSN 1823-884.

xvi. Ngwoke, R.I., (2016), Teacher Availability as a Correlate of Senior Secondary School Pupils' Reading Comprehension Achievement in English Language in Ebonyi State, Nigeria. Retrieved from: http:/ / www.ijird.com

xvii. Ohler, J. (2008). Digital Storytelling in the classroom: New Media Pathways to literacy, learning, and creativity (Corwin Pr, Thousand Oaks, CA)

xviii. Samuels, S.J. (1979). The Method of Repeated Readings. Reading Teacher, 32, 403-408.

xix. Smeda, N., Dakich, E. \& Shardal, N. (2014). The effectiveness of digital storytelling in the classrooms: a comprehensive study. Smart Learning Environments Springer Open Journal 1:6.

xx. Ting, Xiang \& Beng, Kah Seng \& Davidson, (2016). Popularity of Various Teaching Methods in a Post-Secondary Biology Class of a Malaysian Private Institution.AJTLHE :8(1): pp.1-25. ISSN 1985-5826

xxi. Jung, Insung \& Yekyung (2013). YouTube acceptance by university educators and pupils : a cross cultural perspective. Innovations in Education and Teaching International. Volume 52(2015) Issue 3

xxii. Vanderplank. R(1993). A very verbal medium: Language learning through closed captions. TESOL Journal, 3(1),1014.

xxiii. Yunus, M. M. \& Abdullah, N.R.K.R.B.(2011). Motivation and attitudes for learning English among year six students in primary rural school. Procedia-Social and Behavioral Sciences, 15, 2631-2636.

xxiv. Yunus, M.M., Salehi, H., Amini, M., Shojaee, M. \& Wang, Y.F. (2016). Activities and Suggestions For Using Social Networking In Teaching ESL Writing. Journal of Theoretical and Applied Information Technology.84(2):170-182 